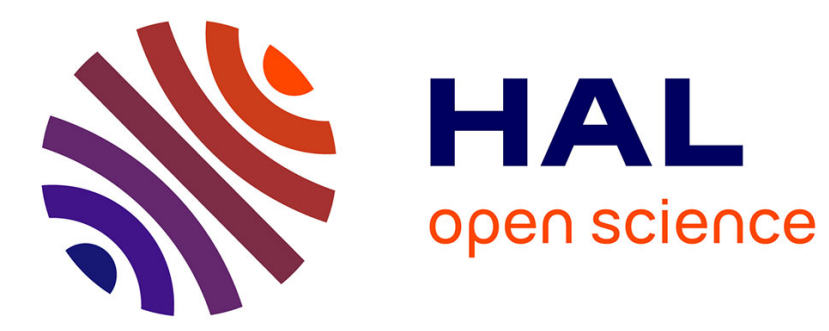

\title{
What history tells us XXXIV. The complex history of the selective model of antibody formation
}

Michel Morange

\section{To cite this version:}

Michel Morange. What history tells us XXXIV. The complex history of the selective model of antibody formation. Journal of Biosciences, 2014, 10.1007/s12038-014-9439-7 . hal-01480378

\section{HAL Id: hal-01480378 \\ https://hal.science/hal-01480378}

Submitted on 6 Mar 2017

HAL is a multi-disciplinary open access archive for the deposit and dissemination of scientific research documents, whether they are published or not. The documents may come from teaching and research institutions in France or abroad, or from public or private research centers.
L'archive ouverte pluridisciplinaire $\mathbf{H A L}$, est destinée au dépôt et à la diffusion de documents scientifiques de niveau recherche, publiés ou non, émanant des établissements d'enseignement et de recherche français ou étrangers, des laboratoires publics ou privés.

\section{(1) (1) $\$$}

Distributed under a Creative Commons Attribution - NonCommercial - NoDerivatives| 4.0 


\section{What history tells us}

XXXIV.

The complex history of the selective model of antibody formation

\section{MICHEL MORANGE}

Centre Cavaillès, République des Savoirs USR 3608, Ecole normale supérieure, 29 rue d'Ulm, 75230 Paris Cedex 05, France

\section{(Fax, 33-144-323941; Email, morange@biologie.ens.fr)}

Keywords: antibody; autocatalysis; clone; enzymatic adaptation; instructive model; protein structure; selective model; sequence

\section{Introduction}

In 1955, Niels Jerne proposed, in the Proceedings of the National Academy of Sciences, "the natural-selection theory of antibody formation": when an antigen is introduced within an organism, pre-existing antibodies interact with it and the complex is captured by cells of the immune system in which the antibody is reproduced (Jerne 1955). Two years later, David Talmage (Talmage 1957) and Frank Burnet (Burnet 1957; the model is developed in Burnet 1959) shifted the level of selection and explanation from the molecular to the cellular level: cells bearing at their surface proteins with a structure complementary to the circulating antigen are activated, and start dividing and secreting large amounts of antibodies with the same binding site as the proteins present on their surface. This selective model of antibody production was in agreement with the new emerging vision of molecular biology in which information for the synthesis of proteins is stored in the genetic material; in contrast with the instructive model of 
antibody formation that had been proposed by Linus Pauling in the 1940s - the incompletely folded molecule of globulin adopts its final conformation and activity by moulding on the antigen molecule (Pauling 1940). Pauling's model was a sophisticated chemical version of models proposed before him. This important shift towards selective models was emphasized by many molecular biologists (Monod 1971). The fact that Jerne's paper was communicated by Max Delbrück, the head of the American phage group, was the sign of this tight association between molecular biology, and the selective model of antibody formation. In parallel, the model of Jacob and Monod replaced previous instructive models to explain the synthesis of adaptive enzymes - the synthesis of antibodies and adaptive enzymes had been often compared. As a non-specialist, I naively accepted this historical description which, in fact, is more retrospective than real. Thanks in particular to the very careful historical study of Thomas Söderqvist (Söderqvist 1994), we now know that the history was much less linear.

\section{Ambiguities in the attribution of the Nobel Prize}

One sign of this complexity is visible in the indirect recognition of the new conception of antibody synthesis by the Nobel Committee. Both Burnet and Jerne received the Nobel Prize, the first in 1960 and the second in 1984. But neither of them was directly honoured for his discovery of the selective model of antibody formation. Burnet and Peter Medawar shared the prize for their discovery and explanation of the phenomenon of immunological tolerance, whereas Jerne shared it with Cesar Milstein and Georges Köhler for "theories concerning the specificity in development and control of the immune system and the discovery of the principle for production of monoclonal antibodies", although Jerne 
admitted during the banquet speech that he "had no part in the monoclonal invention". The titles of their lectures also show that the selective theory was not at the heart of their contributions: Burnet discussed "immunological recognition of self" (Burnet 1960) and Jerne "the generative grammar of the immune system" (Jerne 1984).

\section{The context of Jerne's model}

Söoderqvist has very clearly demonstrated that the model proposed by Jerne was an answer to the difficulties encountered by the instructive model in explaining the characteristics of the immune response. Some of these difficulties had already been discussed by Burnet and Fenner (Burnet 1941; Burnet and Fenner 1949) who had proposed a different model, close to the one initially put forward by Paul Ehrlich (Ehrlich 1900): pre-existing cellular enzymes involved in the elimination of cellular debris interact with antigens, and are later converted into antibodies without enzymatic activity. The increase in the avidity of antibodies during the immune response cannot be explained if the persistent synthesis of antibodies is the direct result of the persistence of the antigen in the immune cells: why would the recurrent moulding of antibodies on the antigen give rise to antibodies with a higher avidity? An increase in the sensitivity of methods for the detection of specific antibodies had yielded results in favour of the existence of natural antibodies, pre-dating any contact between the organism and foreign antigens. These two observations were made by Jerne himself. Interestingly, the second was the result of his contacts with molecular biologists: he exploited the sensitivity of the methods used to count bacteriophages to demonstrate the presence of natural antibodies. However, the value of this experiment was limited 
by the possible previous contamination of animals by bacteria and the bacteriophages that they harbour. More surprising is the mechanism proposed by Jerne. The pre-existing antibodies, recognizing the antigen that has been introduced into the organism, are specifically replicated within cells of the immune system. Jerne mentioned the possible involvement of RNA in this process. The model he advocated was derived from that proposed some years before by Cyril Hinshelwood: a protein was able to control the synthesis of a specific RNA which in turn participates in the reproduction of the protein (Caldwell and Hinshelwood 1950).

There is no trace in this model of DNA and genetic information. The appeal to RNA is an acknowledgement of the numerous observations made by cytologists and biochemists, in particular those of Jean Brachet, showing the involvement of RNA in protein synthesis. There is no reference to the sequence of amino acids in a protein, or to the relation between this sequence and the conformation of the protein. In fact, the mechanism that is proposed is nonexistent.

When, in 1957, Talmage and Burnet proposed shifting the level of selection by the antigen from the molecular to the cellular, they did not propose any precise mechanism of antibody formation. But by hypothesizing that different cellular clones have different synthetic potentials, they made a proposition that was more acceptable than the direct replicative model of Jerne.

\section{Repositioning Jerne's propositions in their right historical context}

Jerne's model was the result neither of the new vision imposed by the Central Dogma of molecular biology, nor of a new 
conception of enzymatic adaptation: both transformations took place later. A precise description of the chronology is needed. In Crick's famous 1957 lecture, what was significant for the question of antibody synthesis was not only the Central Dogma, the description of the flow of information from DNA to RNA and protein and the sequence hypothesis, but also another hypothesis: protein folding is simply a function of the order of amino acids (Crick 1958, 144). Bruno Strasser has convincingly shown that this hypothesis was introduced by Crick under the direct influence of the results obtained some months before by Anfinsen in his in vitro studies of protein renaturation (Strasser 2006). This means that the new conceptions of molecular biology were not accessible to Jerne when he proposed his model. It was the contribution of Joshua Lederberg published in Science in 1959 that rephrased the problem of antibody synthesis within the new molecular paradigm (Lederberg 1959). Vernon Ingram's experiment showing that a mutation in the gene encoding one of the globin chains altered the amino acid sequence of the protein was also posterior to Jerne's model (Ingram 1957). The same is true for enzymatic adaptation. In 1955, the dominant model was that proposed by John Yudkin and adopted by Monod - the inducer binds to a precursor protein and modifies its conformation to generate a new enzymatic activity. Two years earlier, Monod's collaborators still had experimental arguments in favour of the existence of a precursor, $\mathrm{Pz}$ (Pappenheimer 2003). The existence of gratuitous inducers, able to stimulate the synthesis of adaptive enzymes without being their substrates, was not an active challenge to the model.

The reasons Jerne proposed his model were different. As I have already mentioned, the major one was the impossibility 
of accounting for the characteristics of the immune response with the instructive model. The second, emphasized by Söderqvist, was the desire to introduce, under the influence of Delbrück and other molecular biologists, natural selection in the production of antibodies, which for them was the only mechanism capable to generate sufficient diversity. But the third support of Jerne's model was that the notions of autocatalysis and self-replication had been dominant in biology since the 1930s (Olby 1974, chap. 7). They had been used to explain the conversion of proenzymes to enzymes, and adapted to account for the rapid replication of bacteriophages during bacterial infection. Similar mechanisms had been proposed for gene and chromosome replication. The German (and Nazi) physicist Pascual Jordan made self-replication a direct consequence of quantum theory. This idea was criticized and Pauling and Delbrück proposed that the process of replication could occur indirectly, through the formation of a negative replica (Pauling and Delbrück 1940). Direct or indirect self-replication was considered by biologists as a fundamental biological process. Delbrück himself proposed such a model for chromosome replication (Delbrück 1941). When Watson told Jerne that his model "stinks", he was probably referring to the apparent analogy with Jordan's model (Jerne 1966). Therefore, the model of Jerne was both original and the legacy of old, outdated models. Interestingly, ten years after he proposed his model, Jerne still did not understand why his direct mechanism of protein replication has been so rapidly discarded (Jerne 1966).

\section{A rapid proliferation of models}

The new models of Burnet and Talmage were not immediately accepted in the form that they have today. The first production of cellular systems capable of synthesizing antibodies was 
accomplished at the beginning of the 1960s (Fishman 1959; McKenna and Stevens 1960). Fishman rapidly reached the conclusion that two cell types, the macrophage and the lymphocyte, were involved in the formation of antibodies. The antigen is engulfed by the macrophage, which produces an RNA that is transmitted to the lymphocyte in which antibody production takes place (Fishman 1961; Fishman and Adler 1963; Pinchuck et al. 1968). The same idea that RNAs could transfer the information for antibody production between cells was simultaneously proposed by another group (Mannick and Egdhal 1962). Without describing precisely the relation between the antigen and the RNA synthesized by the macrophage, this model was obviously more instructive than selective. Similar transfers of information through RNA molecules were simultaneously proposed for the induction of differentiation (Niu 1958) and in the case of memories (see Morange 2006).

In a different way, Lederberg and Burnet did not exclude the possibility that the synthesis of antibodies could be due to selfreplicating cytoplasmic particles, equivalent to plasmagenes, the role of which had been advocated by Sol Spiegelman (Spiegelman 1956). Jack Schultz (Schultz 1959) also did not exclude the possibility that chromosomal DNA might be directly modified by the antigens. Different models of antibody synthesis coexisted in the years that immediately followed the emergence of the selective model of antibody formation. Many years passed before the emergence of a full molecular description of the mechanism of antibody production.

\section{Conclusion}

Two lessons emerge from this brief description of Jerne's contribution to the selective model of antibody synthesis. The 
first is the vagueness of the first models produced by Jerne, but also by Burnet and other supporters of the selective theory, in comparison with the precise physical-chemical model proposed by Pauling as early as 1940 . Whereas the characteristics of protein structure were at the core of the instructive model, they were not essential for the acceptance of the selective one.

The second lesson concerns the precise chronological study that is required to fully appreciate any contribution to the construction of scientific knowledge, and to avoid a retrospective interpretation. Jerne's model was neither supported by the Central Dogma of molecular biology nor by a new conception of enzymatic adaptation, both of which saw the light of day between 1955 and 1957. This does not diminish the merit of Jerne. He was able to see beyond the false evidence that there was an infinite number of antibodies, a consequence of the observations made by Landsteiner that any modification of a chemical motif could give rise to a new antigen (Landsteiner 1936). By supposing that fewer than one million different antibodies were sufficient to account for the immune response, he opened a space for a selective theory of adaptive immunity. His second merit was to have understood the full creative power of a selective process, the only type of mechanism able to explain the efficiency of the immune system.

\section{Acknowledgements}

I am indebted to David Marsh for critical reading of the manuscript.

\section{References}


Burnet FM 1941 The production of antibodies (Melbourne: Macmillan)

Burnet FM 1957 A modification of Jerne's theory of antibody production using the concept of clonal selection. Australian J. Sci. 20 67-69

Burnet FM 1959 The clonal selection theory of acquired immunity (Cambridge: Cambridge University Press)

Burnet FM 1960 Immunological recognition of self. Nobel lecture

Burnet FM and Fenner F 1949 The production of antibodies $\left(2^{\text {nd }}\right.$ ed.) (Melbourne: Macmillan)

Caldwell PC and Hinshelwood C 1950 Some considerations on autosynthesis in bacteria. J. Chem. Soc. 3156-3159

Crick FHC 1958 On protein synthesis. Symp. Soc. Exptl. Biol.

12 138-163

Delbrück M 1941 A theory of autocatalytic synthesis of polypeptides and its application to the problem of chromosome reproduction. Cold Spring Harbor Symp. Quant. Biol. 9 122-124

Ehrlich P 1900 On immunity with special reference to cell life. Proc. Roy. Soc. London Ser. B 66 424-448

Fishman M 1959 Antibody formation in tissue culture. Nature 183 1200-1201

Fishman M 1961 Antibody formation in vitro. J. Exp. Med. 114 837-856

Fishman M and Adler FL 1963 Antibody formation initiated in vitro II. Antibody synthesis in X-irradiated recipients of diffusion chambers containing nucleic acid derived from macrophages incubated with antigen. J. Exp. Med. 117 595602

Ingram VM 1957 Gene mutations in human haemoglobin: the chemical difference between normal and sickle cell haemoglobin. Nature 180 326-328 
Jerne NK 1955 The natural-selection theory of antibody formation. Proc. Natl. Acad. Sci. USA 41 849-857 Jerne NK 1966 The natural selection theory of antibody formation: ten years later. In Phages and the origins of molecular biology, Cairns J, Stent GS and Watson JD eds. (Cold Spring Harbor: Cold Spring Harbor Laboratory Press) pp 301-312

Jerne NK 1984 The generative grammar of the immune system. Nobel lecture

Landsteiner K 1936 The specificity of serological reactions (Cambridge: Harvard University Press)

Lederberg J 1959 Genes and antibodies. Science 129 16491653

Mannick JA and Egdahl RH 1962 Ribonucleic acid in "transformation" of lymphoid cells. Science 137 976-977 McKenna JM and Stevens KM 1960 Studies on antibody formation by peritoneal exudate cells in vitro. J. Exp. Med. $111573-600$

Monod J 1971 Chance and necessity: an essay on the natural philosophy of modern biology (New York: Knopf)

Morange M 2006 The transfer of behaviours by macromolecules. J. Biosci. 31 323-327

Niu MC 1958 Thymus ribonucleic acid and embryonic differentiation. Proc. Natl. Acad. Sci. USA 44 1264-1274 Olby R 1974 The path to the double helix (London: Macmillan)

Pappenheimer AM Jr. 2003 Whatever happened to Pz? In Origins of molecular biology: a tribute to Jacques Monod, Ullmann A ed. (Washington: ASM Press) pp 69-75 Pauling L 1940 A theory of the structure and process of formation of antibodies. J. Am. Chem. Soc. 62 2643-2657 
Pauling L and Delbrïck M 1940 The nature of the intermolecular forces operative in biological processes.

Science 92 77-79

Pinchuck P, Fishman M, Adler FL and Maurer PH 1968 Antibody formation: initiation in "nonresponder" mice by macrophage synthetic polypeptide RNA. Science 160 194-195 Schultz J 1959 Antigens and antibodies as cell phenotypes. Science 129 937-943

Söderqvist T 1994 Darwinian overtones: Niels K. Jerne and the origin of the selection theory of antibody formation. $J$. Hist. Biol. 27 481-529

Spiegelman S 1956 Enzymes: units of biological structure and function (New York: Academic Press)

Strasser B 2006 A world in one dimension: Linus Pauling, Francis Crick and the Central Dogma of molecular biology. Hist. Phil. Life Sci. 28 491-512

Talmage DW 1957 Allergy and immunology. Annu. Rev. Med. 8 239-256 